\title{
Intellectual Property in Post-Corona Times: Managing the Future
}

\author{
Oliver Baldus ${ }^{1 *}$, Thomas Heinz Meitinger ${ }^{2}$ \\ ${ }^{1}$ Splanemann Patent Attorneys, Munich, Germany \\ ${ }^{2}$ Meitinger \& Partner Patent Attorneys, Munich, Germany \\ Email: ‘baldus@lean-ip.org
}

How to cite this paper: Baldus, O., \& Meitinger, T. H. (2020). Intellectual Property in Post-Corona Times: Managing the Future. American Journal of Industrial and Business Management, 10, 1430-1436.

https://doi.org/10.4236/ajibm.2020.108093

Received: July 28, 2020

Accepted: August 21, 2020

Published: August 24, 2020

Copyright $\odot 2020$ by author(s) and Scientific Research Publishing Inc. This work is licensed under the Creative Commons Attribution International License (CC BY 4.0).

http://creativecommons.org/licenses/by/4.0/

\begin{abstract}
After Corona times companies are more reliant on the optimum usage of their scarce production resources, like financial or human capital. Intellectual property, like patents, must be used as efficiently as possible. In this context, it is required to focus available financial resources on those property rights that yield to the greatest impact. Other patents that protect subject-matter of little or no interest to market participants waste company resources and form negative financial assets. Such subject-matter does not require patents as prohibition rights, since market participants voluntarily choose not to use the invention. Surprisingly, many firms often hold numerous self-generated patents, which they would never be willing to purchase from a third party. The methods of Lean IP facilitate cost savings for patent portfolio management of up to $90 \%$ without any loss of its original impact. All tools of Lean IP Management are directed to cost efficient handling of IP rights, while IP rights that form negative assets are consequently abandoned. One of the basic principles of Lean IP is: "Better few diamonds than tons of coal".
\end{abstract}

\section{Keywords}

Patents, Intellectual Property, Lean-IP, Corona, Controlling, Increasing Profits and Efficiency of Intellectual Property

\section{Introduction}

The Corona crisis has led to a global lockdown of many economic activities aimed at protecting the health of citizens. The lockdown has affected the entire global economy and international supply chains. To mitigate its economic effects, governments have promised the markets trillions of dollars in bailouts. For example, the US government has signed off on a $\$ 2$ trillion stimulus package for the American economy (Cooper et al., 2020), and the European Union has as- 
sembled a $€ 500$ billion rescue package for its member states (Pieters, 2020). In addition countless national monetary auxiliary programs have been launched. In this way tremendous amounts of money have been injected into markets hit by both, declining supplies and demands of many goods and services. The result is a bloated money supply confronting a shrinking offering of products, known as a supply shock, accompanied by a demand shock, i.e. rapidly falling demand (Samuelson, 2020).

Most economists assume that in this situation so-called stagflation will occur (Olson, 1982). Stagflation-composed from the words stagnation and inflationdescribes a state of high inflation during an economic slowdown phase, while unemployment remains steadily high. In terms of decision-making stagflation is a challenge for economic policy, since all measures intended to lower inflation may increase unemployment. There are very few historical examples of stagflation, the most prominent being the 1970s oil crisis. It is assumed that stagflation periods last several years, during which consumer markets remain fragile (Shama, 1978). During such times re-nationalisation of supply chains will take place and companies are extremely reliant on the optimum usage of their scarce production resources, like financial or human capital.

\section{Intellectual Property as It Was Before-An Honest View}

The necessity of IP rights within the realm of national economics has been debated long and controversially. Although the term "patent" carries extraordinary positive connotations for most market participants, within macroeconomics, i.e. the economy as a whole, positive or negative effects of patent rights cannot be answered with certainty. Despite various theories for macroeconomically justifying patent systems, none of them provides enough explanations. For example, reward or social contract theories are the most common positive patent theories. These explain the economic utility of patents as an ex-post reward for the inventor as compensation for his labour and disclosing his invention to the public. This reward is supposed to encourage inventors to enhance public general technological knowledge, which in turn is responsible for increasing social welfare. Nevertheless, it is questionable whether these theories can be appropriately applied to modern national economies for substantiating welfare gains (Baldus, 2010).

In terms of social welfare economics this substantiation boils down to the question whether a world without patents would be better, worse or like the one we currently live in. The answer cannot be given as a pure matter of principle, since we will never know what a world without IP rights would be like (Machlup, 1958; Penrose, 1951) ${ }^{1,2}$. However, many people believe that a world without

${ }^{1}$ (Machlup, 1958): "If we did not have a patent system, it would be irresponsible, on the basis of our present knowledge of its economic consequences, to recommend instituting one. But since we have had a patent system for a long time, it would be irresponsible, on the basis of our present knowledge, to recommend abolishing it."

${ }^{2}$ (Penrose 1958): "If national patent laws did not exist, it would be difficult to make a conclusive case for introducing them; but the fact that they do exist shifts the burden of proof and it is equally difficult to make a really conclusive case for abolishing them.” 
IP rights would be exactly like the world today, since inventions accompanied mankind long before patent law and are inherent to all human beings. If this assumption were true, IP rights would merely place social costs on societies, so that national economies without an IP rights system could yield competitive gains. In general, all monopolies, such as granted patents, cause deadweight losses so that they are to be considered as suboptimum in comparison to perfect competition (Varian, 2014). Therefore, it remains unclear whether positive effects from patents can outweigh their negative monopoly harms with respect to the economy as a whole.

In addition, IP rights are strongly bound to nations that grant not only strong property rights but also liberty to its citizens. Therefore, there is a strong correlation between property rights and liberty. Liberty is a strong requisite for property and vice versa. A further prerequisite for IP rights is a reliable and independent legal system for enforcing them. IP rights have never played an important role in autocratic or communist nations, such as Turkey or the Soviet Union; state-run companies regularly do not need patents since they have no competitors. Only in a fistful of nations, like the US, the UK, Japan and Germany, IP rights are predominant. In general, there seems to be a trade-off between the extent of government interventions in markets and the importance of IP rights (Hayek, 1978) ${ }^{3}$. In short, the more a market is subject to intervention regulations, the lower the relevance of intellectual property for its goods.

But not only in macroeconomics, also in microeconomics, i.e. with respect to individual firms, the influence of IP rights is lower than commonly expected. In pre-Corona times it was estimated that $85 \%$ to $90 \%$ of patents do not contribute to companies' economic success (Bartenbach \& Volz, 2014; Mittelstaedt, 2016). An Australian study revealed that only $30 \%$ of patents are vaguely believed by their respective inventors to have been infringed upon. However, actual infringement rates seem even lower, since only in half of cases were at least rudimentary steps taken towards enforcement (Weatherall \& Webster, 2010). In addition, traditional theories (Ensthaler \& Strübbe, 2006; Grünewald \& Wurzer, 2012) for monetary evaluating patents and determining their financial value only yield unprovable or insufficient results (Baldus \& Heckmann, 2012).

In fact, most patents protect subject-matter of little or no interest to market participants. Such subject-matter does not require patents as prohibition rights, since market participants voluntarily choose not to use the invention. Although existent in principle, the granted prohibition right in these cases cannot be executed due to a missing infringer. Surprisingly, many firms often hold numerous self-generated patents, which they would never be willing to purchase from a third party (Baldus et al., 2018). In this case the internal perspective of the firm does not coincide with the external view onto it. Furthermore, modern companies sometimes even decide not to actively follow a patent strategy (Abrams, 2014).

\footnotetext{
3"There can be no freedom of the press if the instruments of printing are under government control, no freedom of assembly if the needed rooms are so controlled, no freedom of movement if the means of transport are a government monopoly." (cf. (Hayek, 1978)).
} 
In summary, intellectual property before Corona seemed to be inefficient and most likely caused welfare losses from the macroeconomic perspective as well as wasting of resources from the microeconomic perspective. Although most people do not like to hear, concrete positive effects of patents were difficult to prove even before the Corona virus struck.

\section{Intellectual Property Afterwards}

In response to the new Corona crisis economic disruptions and instability will occur, inflicting a tremendous financial burden on most companies. Further, a $\mathrm{V}$-shaped recovery of national economies becomes less likely the longer the crisis lasts. In addition, it cannot be estimated how governments will behave in future with respect to nationalisation of companies and socialisation of IP assets. In reaction to the crisis, Germany has already decided on possible official directives that would allow certain inventions to be used without the patent owner's approval if deemed necessary for supplying the public with essential goods ${ }^{4}$. In reaction to the crisis it is currently also unclear if modern industrial societies will remain civil libertarian democracies or become more socialist regimes with less protection of intellectual property rights. Customer demand will quickly shift from markets for technological goods to those for essential goods. In addition, it is uncertain if markets and businesses will be temporarily shut down again. Market shifts or lockdowns will also affect the value of IP assets that are protecting goods traded on these markets. Globalisation will presumably turn back not only to re-nationalisation but also internalisation of supply chains, so that components are produced internally within the firm and companies will operate more autonomously. In these cases, patents are not required for fending off competitors. In summary the economically debateable IP system hangs now even more in the balance.

In this new context the question arises how the Corona crisis will influence the existing IP landscape and how companies should manage and reconsider their IP in future. As stated above, patents are something of a luxury whose economic effects in many cases are questionable. However, only the strongest companies will survive the crisis. In order to belong to this category, it is extremely important to avoid squandering scarce resources and use patents only where they will have the greatest impact (Baldus \& Heckmann, 2017).

In contrast to the aforementioned theories, Lean IP management determines the value of a patent in correspondence to the protected product's market potential. In this view the value of a patent is a direct proxy of the market value of the protected subject-matter. If there is no buyer willing to buy the protected product, there will be no buyer for its patent (Baldus et al., 2018). The higher the possible sales revenue of the protected product is, the higher the value of the corresponding patent. In case of missing revenues, the value of the patent is negative, i.e. a negative asset, due to its granting costs and annuity fees. Thus, it

${ }^{4} \S 5$ Abs. 2 Nr. 5 IfSG (German Infection Protection Act). 
is necessary re-focus and concentrate IP rights on key-asset-protecting patents in order to remain successful and profitable in the future.

Lean IP management cannot recognize key patents from a portfolio that protect top-selling products, but it can identify worthless patents, i.e. patents protecting subject-matter without market relevance, by analysing the patent claims. In Lean IP, the latter must be identified and jettisoned from the portfolio to save precious financial resources. For future key players it will be crucial to abandon all patents that do not contribute to a company's success and waste financial resources. In future it will be better to safeguard only a few carefully selected golden eggs and discard the rest (Barth \& Baldus, 2019). Thus, freed resources must be reinvested for generating more golden eggs.

Patent applications should be kept as lean and smart as possible as well. In principle, patent applications could basically rely with regards to content on the claims solely without an extensively written description section, if few drafting requirements are addressed (Baldus et al., 2019). By using concise language instead of verbose descriptions containing irrelevant information, drafting costs, translation costs and costs for handling patent applications can be drastically reduced. In this way the efficiency of Lean IP Management can be further increased in addition to merely culling negative patent assets.

In order to meet the Lean IP criteria each patent claim of a patent application should cover a product with market potential. In contrast, it is not necessary to draft patent claims to get patents for grantable but economically useless subject-matter, like non-corrosive golden anchors ${ }^{5}$. If it is not possible that a not yet granted patent application leads to a patent for a product having high market relevance, it must be abandoned to save resources. In the same way, patent opposition procedures do not require a complete destruction of the challenged patent, but only those claims that protect relevant market positions, i.e. the prohibition rights that hinder.

Further, portfolios need to be reshaped not only to hit competitors but also both, supply and demand companies within the own supply chain. This would increase bargaining power over these companies in negotiations (Baldus \& Heckmann, 2016; Baldus \& Heckmann, 2011). Lean IP Management is focused on the market potential of the protected product and offers an array of tools for tremendous cost savings while preserving competitiveness and enhancing future cash flow. These uncertain Corona times open a window of opportunity perfectly suited for justifying out-of-favour measures and shedding ancient IP habits.

\section{Summary}

Only those companies will survive the Corona crisis that uses their potential and resources most efficiently. However, companies that ignore these fundamental principles will perish and die. A serious crisis should not go to waste. Therefore,

${ }^{5}$ The "golden anchor" patent stands for a patent that is legally grantable, but economically worthless, since there is no market for golden anchors on ships (cf. (Baldus et al., 2018)). 
the Corona crisis must not be seen as a pure disaster, but as a chance for evolution in terms of IP to a more efficient regime. In fact, the current situation offers excellent opportunities for eliminating many traditional inefficiencies.

In this way, the Corona crisis offers an ideal opportunity to discard longstanding rigidities by introducing Lean IP Management. Lean IP Management facilitates cost savings for patent portfolio management of up to $90 \%$ without any loss of its original impact. All tools of Lean IP Management are directed to cost efficient generation, organisation and handling of IP rights. A consequent compliance to Lean IP measures is one of many bricks to ascertain companies' survival in future.

\section{Conflicts of Interest}

The authors declare no conflicts of interest regarding the publication of this paper.

\section{References}

Abrams, A. (2014). Tesla Opens Its Patents to Everyone. Time Magazine.

Baldus, O. (2010). Patent-Based Cooperation Effects. Journal of IP Law and Practice, 5, 111. https://doi.org/10.1093/jiplp/jpp216

Baldus, O., \& Heckmann, C. (2011). Horizontal Patents, Commercial Benefit, and Sophisticated Patent Strategies. Journal of Intellectual Property Law \& Practice, 6, 401. https://doi.org/10.1093/jiplp/jpr028

Baldus, O., \& Heckmann, C. (2012). Informal Restrictions and Evaluation of Patents. Journal of Intellectual Property Law \& Practice, 7, 613. https://doi.org/10.1093/jiplp/jps091

Baldus, O., \& Heckmann, C. (2016). Increasing Profits by Strategic Patenting-A Change of Perspective from Bottom-Up to Top-Down. American Journal of Industrial and Business Management, 6, 958. https://doi.org/10.4236/ajibm.2016.69093

Baldus, O., \& Heckmann, C. (2017). Lean IP-Management-Savings Costs for IP Management Based on a Paradigm Change in Assessing Inventions. American Journal of Industrial and Business Management, 7, 760. https://doi.org/10.4236/ajibm.2017.76054

Baldus, O., Barth, M., \& Heckmann, C. (2019). Lean Applications for Lean IP Management. Journal of Intellectual Property Law \& Practice, 14, 93. https://doi.org/10.1093/jiplp/jpy165

Baldus, O., Dübon, P., \& Barth, M. (2018). On the Value of Patents in Lean IP Management. American Journal of Industrial and Business Management, 8, 1113. https://doi.org/10.4236/ajibm.2018.85077

Bartenbach, K., \& Volz, F.-E. (2014). Arbeitnehmererfindungsgesetz ArbEG (p. 952). Köln: Carl Heymanns.

Barth, M., \& Baldus, O. (2019). Managing Patent Portfolios-Lean IP Management versus Discount IP Management or Better Few Diamonds than Tons of Coal? American Journal of Industrial and Business Management, 9, 1901. https://doi.org/10.4236/ajibm.2019.910123

Cooper, M. et al. (2020). Trump Signs $\$ 2$ Trillion Bill as U.S. Virus Cases Pass 100,000. NY Times.

Ensthaler, J., \& Strübbe, K. (2006). Patentbewertung-Ein Praxisleitfaden zum Patentma- 
nagement (p. 113). Berlin: Springer Verlag.

Grünewald, T., \& Wurzer, A. J. (2012). Monetäre Patentbewertung nach DIN 77100 (p. 81). Berlin: Beuth Verlag.

Hayek, F. A. (1978). New Studies in Philosophy, Politics, Economics, and the History of Ideas (p. 149). Chicago, IL: University of Chicago Press. https://doi.org/10.7208/chicago/9780226321288.001.0001

Machlup, F. (1958). An Economic Review of the Patent System. In Study of the Subcommittee on Patents, Committee on Judiciary, U.S. Congress, 85th Congress, $2 d$ sess. Pursuant to S. Res. 236, Study No. 15.

Mittelstaedt, A. (2016). Intellectual Property Management (p. 96). Berlin: Springer Gabler. https://doi.org/10.1007/978-3-658-02992-0

Olson, M. (1982). The Rise and Decline of Nations: Economic Growth, Stagflation and Social Rigidities. New Haven, CT: Yale University Press.

Penrose, E. T. (1951). The Economics of the International Patent System. Baltimore, MD: John Hopkins University Press.

Pieters, J. (2020). Europe Commits to $€ 500$ Billion Coronavirus Support Package; "Sensible and Solidary", Dutch FM Says. NL Times.

Samuelson, R. J. (2020). All Our Choices Are Bad-But Some Are Worse. The Washington Post.

Shama, A. (1978). Management \& Consumers in an Era of Stagflation. Journal of Marketing, 42, 43. https://doi.org/10.2307/1250533

Varian, H. R. (2014). Intermediate Microeconomics: A Modern Approach (Ninth International Student ed., p. 465). New York: W.W. Norton \& Company.

Weatherall, K. G., \& Webster, E. (2010). Patent Infringement in Australia: Results from a Survey. Federal Law Review, 38, 21-70. https://doi.org/10.1177/0067205X1003800102 